\title{
IAMJ
}

INTERNATIONAL

AYURVEDIC

MEDICAL JOURNAL

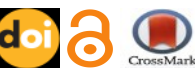

\section{EFFECT OF TARAKESWARA RASA IN MICROALBUMINURIA ASSOCIATED WITH TYPE (II) DIABETES MELLITUS - A CLINICAL STUDY}

\author{
Krishnaveni. $\mathbf{R}^{1}$, Jacob. M. Titus ${ }^{2}$, T.V. Sreeni ${ }^{3}$ \\ ${ }^{1}$ Assistant Professor, Department of Rasashastra and Bhaisajyakalpana, Government Ayurveda College, Kannur, \\ Kerala, India \\ ${ }^{2}$ Retired Professor, Department of Rasashastra and Bhaisajyakalpana, Government Ayurveda College, Trivandrum, \\ Kerala, India \\ ${ }^{3}$ Professor, Department of Rasashastra and Bhaisajyakalpana, Government Ayurveda College, Trivandrum, Kerala, \\ India
}

Corresponding Author: krishnaaingr@gmail.com

https://doi.org/10.46607/iamj04p5022021

(Published online: January 2021)

Open Access

(C) International Ayurvedic Medical Journal, India 2021

Article Received: 18/12/2020 - Peer Reviewed: 04/01/2021 - Accepted for Publication: 15/01/2021

Check for updates

\begin{abstract}
Microalbuminuria associated with Type (II) Diabetes mellitus is a strong predictor of upcoming Diabetic Nephropathy. It is a major cause of Diabetic kidney disease, leading to mortality and morbidity in these patients. The cost of treatment in a Diabetic kidney disease is huge; the cost may further escalate unless prevention and intervention are initiated at an earlier stage, which would help in minimizing further complications. The current treatment modalities of ACE inhibitors and RAS blockades alone cannot support this disease. Ayurveda with its array of herbal and mineral medicines has been used for managing this disease and its complications. Tarakeswara Rasa is one such formulation used in managing Diabetes. It is a herbo-mineral formulation containing Rasasindoora, Loha, Vanga and Abraka Bhasmas each of which are potent Rasa Rasayana's used in treating Diabetes. The study drug was meticulously prepared and analyzed for XRD, XRF, PSA etc. An interventional study was conducted for evaluating the effect of Tarakeswara Rasa in 20 Type (II) Diabetic patients having Microalbumin from 30-300mg/g. Tarakeswara rasa with a dosage of $125 \mathrm{mg}$ was administered twice daily with honey and Udumbaraphala (fig's)
\end{abstract}


$3 \mathrm{~g}$ as Anupana (vehicle). The patients were asked to follow a strict diet and exercise regimen for a period of 1 month. The outcome variables such as level of Microalbumin in urine, FBS, PPBS, HbA1c, Urinary sugar and albumin, Blood Pressure and Serum cholesterol were analyzed using paired ' $t$ ' test and symptomatic change analyzed before and after treatment using Wilcoxon signed rank test. The results showed that, the study drug Tarakeswara Rasa is effective in managing Microalbuminuria associated with Type (II) Diabetes Mellitus supported by laboratory findings and also improves the overall quality of life of Diabetic patients.

Keywords: Diabetes Mellitus; Microalbuminuria; Tarakeswara Rasa; Rasa Rasayana

\section{INTRODUCTION}

Diabetes accounts for 1.5 million deaths annually, ranking fourth under Non-Communicable Diseases. Under WHO a Global action plan for the prevention and control of NCDs 2013-2020 was brought up. In the year 2016, they have conducted a campaign aiming to scale up prevention, strengthen care, and enhance surveillance of Diabetes. It aims at using both contemporary and traditional modalities to address this current health scenario. In India it is expected that about 500 million people are using various traditional drugs coming under AYUSH for various healthcare needs.

\section{Background of the study}

Diabetes mellitus is reaching potentially epidemic proportions in India with 62 million diabetic individuals currently diagnosed with the disease ${ }^{(1)}$. According to Wild et al ${ }^{(2)}$ the prevalence of Diabetes is predicted to double globally from 171 million in 2000 to 366 million in 2030 with a maximum increase in India of 79.4 million. There is much higher prevalence of the disease in southern India compared to other parts as per Indian Council of Medical Research ${ }^{(3)}$, with Kerala sharing $20 \%$ and its state capital Trivandrum at 16\%. An upsurge in early onset of Diabetes is also responsible for a spectrum of Diabetic complications in which $21.1 \%$ are of renal issues seen especially in south Indian population $^{(4,5)}$. Diabetic nephropathy accounts for no less than $46 \%$ of chronic kidney disease ${ }^{(6)}$. Thirty-one percentage of the end stage kidney disease population come under Diabetic kidney disease in India ${ }^{(7)}$. The level of morbidity and mortality due to Diabetes and its complications are enormous which pose significant healthcare burden on affected families, society and the country. The average cost of treatment of Diabetics with chronic kidney disease can go up to INR 100,000
${ }^{(8)}$. The cost of treatment may further escalate unless intervention is initiated at an earlier stage aiming at minimizing the complications. Higher prevalence ${ }^{(9)}$ of $\mathrm{Mi}$ croalbuminuria (37\%) in Type (II) Diabetes mellitus is a predictor of upcoming Diabetic nephropathy.

\section{Need and significance of the study}

With the current treatment modalities being ACE inhibitors and RAS blockades, which cannot completely address the issue effectively, one tends to look upon towards alternative systems of medicine for management. Ayurveda has been addressing the disease and its complications for several years. Apart from the various herbal preparations, Rasaushadhis (herbo mineral drugs) differ from others in having a more quick and specific action pertaining to dhatu (tissue) levels. Studies have been reported with proven clinical efficacy of various bhasmas which used in Prameha (diabetes) Chikitsa. The practice of using Parada (mercury)and allied minerals/metallic's for therapeutic purposes which not only act against the disease but go beyond and becomes Rasayanas pertaining to those specific diseases are called as "RasaRasayanas". Tarakeswara rasa explained in Bahumutrata (urinary disorders) is a fast-acting yoga containing Rasasindoora which itself is a Rasayana and Yogavahi Dravya. It also contains Abraka, Vanga and Loha Bhasmas (incinerated biotite mica, tinand iron micro-nano powder) which are of $R a$ sayana Guna used widely as Pramehagna Aushadhas in daily clinical practice. The potency of the yoga is enhanced by the combination of all four bhasmas and thereby may prove to be effective in controlling Madhumeha, delay its Upadrava Vyadhis (diabetic complications) and bring about a better effect in controlling Microalbuminuria. By this, the yoga can be 
added to the current clinical practice for controlling Diabetes and its various complications which can further help in significant improvement of one's quality of life. This would also help in mainstreaming Rasasastra in the curative field of diabetic pathologies, along with that it would give an insight on the safety and efficacy on rasa preparations to ensure a more fearless, widespread usage of the same.

Objective of the study: To assess the effect of Tarakeswara Rasa in Microalbuminuria associated with Type (II) Diabetes Mellitus.

Research hypothesis: Tarakeswara Rasa is effective in the management of Microalbuminuria associated with Type (II) Diabetes Mellitus

\section{Materials \& Methods}

\section{Study design}

The study was designed as single group Interventional [pre and post] study. The participants were initially screened and later selected into study group according to the given inclusion and exclusion criteria. Total 20 patients were selected for the study and a detailed examination was undertaken before and after the study with the help of case Performa and blood-urine reports. Study setting: Outpatient Department of Rasashastra and Bhaishajyakalpana (R\&B), Government Ayurveda College Hospital, Thiruvananthapuram

Study population: An accessible population of both males and females between the age group 30-70 years with Microalbuminuria associated with Type (II) Diabetes Mellitus attending the OPD of R\&B. Information about the clinical study was given to major newspapers through public relations Department Government of Kerala Trivandrum.

Study period: Total duration of the study was 30 days. Ethical clearance: Ethical clearance was obtained from the Institutional ethical committee.

Informed consent: Informed consent was obtained from all of the study samples.

Interventional schedule: It contains only a single group to which the study drug was given.

Study drug schedule: Tarakeswara Rasa was made according to the yoga mentioned in the text Basavarajeeyam Bahumutra Adhyaya (10), was provided in packets of $125 \mathrm{mg}$ and was administered twice daily along with 2-3 drops of honey after food, for 30days. Subsequently dried Udumbaraphala (fig fruit) of $3 \mathrm{~g}$ was to be taken with warm water. The patient was also advised to follow a strict diet and exercise routine.

\section{Criteria for selection of patient}

Inclusion criteria: Type (II) Diabetes Mellitus patients of age group 30-70 years with Urinary Microalbumin 30-300mg/g.

Exclusion criteria: Pregnancy, lactation, chronic renal failure, Paralysis, patients undergoing dialysis/requiring transplantation and patients with uncontrolled Diabetes mellitus were excluded.

Sample size: 20 patients

Sampling technique: Consecutive selection of patients from accessible population till attaining the sample size.

Data collection: Primary data-interview \&lab investigations

Study tool: Case proforma, Laboratory investigations Assessment Criteria

1. Changes in blood sugar levels-FBS, PPBS, $\mathrm{HbA}_{1} \mathrm{C}$ levels

2. Urinary sugar, albumin and Microalbumin levels

3. Serum cholesterol, Systolic and Diastolic blood pressure levels

4. Changes in Agni, Kosta, Prabhuta and Avila Mutrata, Daurbalya, Thrishna, Karapada Daha, Atisweda, Daurgandya, Pindikodwestana, Sopha, Vrana etc.

5. Changes in Nocturia, pruritis, drowsiness, restricted activity towards end of the day, joint pain, numbness, increased thirst, dryness of mouth and lips, loss of breath were also noted.

6. Other associated changes pertaining to blood parameters and quality of life of patient were also noted.

\section{Assessment of treatment response}

After one month of treatment with the drug, response was assessed. A follow up of one month was also carried out. During this period strict diet and exercise was followed with no drug intervention. Blood reports were again taken to assess and compare changes with after treatment results. 


\section{Data analysis}

1. Socio- Demographic data

2. Data related to general condition of patient

3. Data related to DM and complications

4. Data related to Response to treatment with respect to symptoms

5. Data related to clinical and blood urine parameters
Statistical analysis: The data collected on various parameters from 20 patients were subjected to data analysis using appropriate statistical techniques. Frequency, percentage, mean and standard deviation were calculated for summarizing the raw data. The pre-post analysis of data was done by paired t test. Grading of presenting complaints before and After Treatment was done by Wilcoxon's signed rank test. Diagrams and charts regarding the findings were also included.

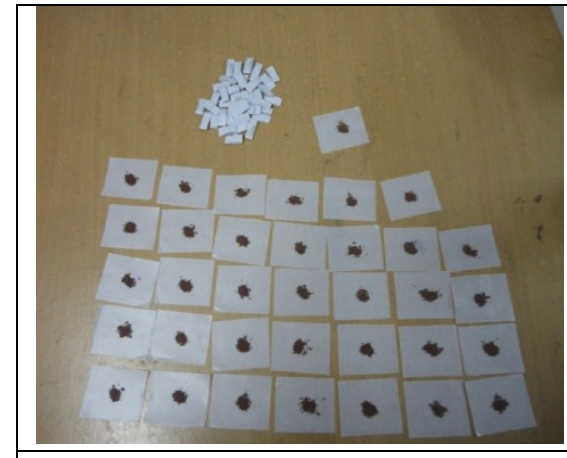

Figure 1: Tarakeswara Rasa $125 \mathrm{mg}$ Packaging.

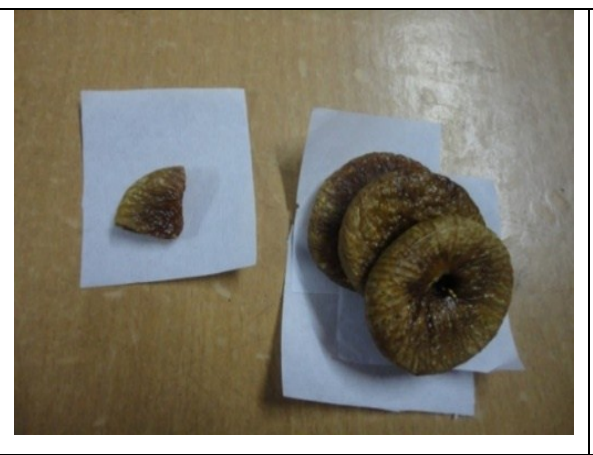

Figure 2: Dried udumbaraphala, $3 \mathrm{~g}$ as Anupana.

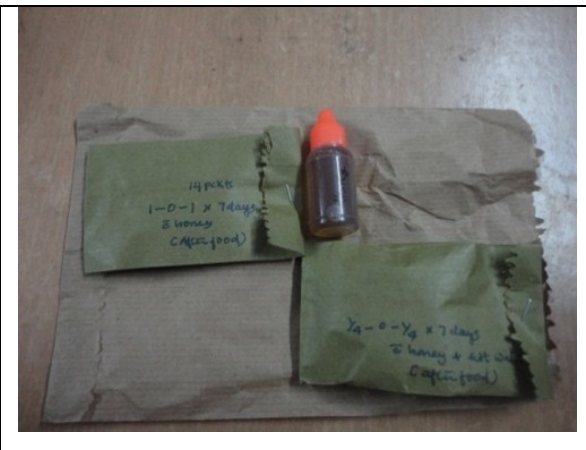

Figure 3: Weekly dispensing dosage of Tarakeswara Rasa,Honey and Udumbaraphala.
Results: The data relating to symptoms were collected and calculated the frequencies $(\mathrm{N})$ and percentage (\%) of each category. In order to test the significance of treatment, effect on these parameters was measured by Wilcoxon signed rank test before and after treatment and respective $p$ values were found out. The details are given in the following tables. The result is: - Highly significant if $p<0.001$, Moderately Significant if $p<$ 0.01 , Significant if $p<0.05$, Not significant if $p>0.05$.
The data relating to laboratory investigations such as FBS, PPBS, HbAlc, Microalbumin, Urinary sugar, Urinary albumin, Serum cholesterol and Blood pressure values were collected, the mean and standard deviation of each category were calculated. In order to test the significance of treatment, effect on these parameters were measured by paired't' test. The details are given in the following tables.

Table 1: Analysis and comparison of effectiveness of intervention in FBS.

\begin{tabular}{|l|l|l|l|l|l|}
\hline & N & \multicolumn{2}{|c|}{ FBS } & Paired t test \\
\cline { 3 - 6 } & & Mean & Sd & t & P \\
\hline BT & 20 & 135.45 & 42.47 & 4.315 & $<0.001$ \\
\hline AT & 20 & 108.75 & 25.19 & & \\
\hline
\end{tabular}

Table 2: Analysis and comparison of effectiveness of intervention in PPBS.

\begin{tabular}{|l|l|l|l|l|l|}
\hline & N & PPBS & Paired t test & p \\
\cline { 3 - 4 } & & Mean & Sd & t & $<0.001$ \\
\hline BT & 20 & 215.00 & 38.57 & 7.273 & 27.38 \\
\hline AT & 20 & 160.30 & & \\
\hline
\end{tabular}


Table 3: Analysis and comparison of effectiveness of intervention in $\mathrm{HbA}_{1 \mathrm{C}}$

\begin{tabular}{|l|l|l|l|l|l|}
\hline & $\mathrm{N}$ & HbAtc & Paired t test \\
\cline { 3 - 6 } & & Mean & Sd & T & P \\
\hline BT & 20 & 7.57 & 1.04 & 9.476 & $<0.001$ \\
\hline AT & 20 & 6.21 & 0.67 & & \\
\hline
\end{tabular}

Table 4: Analysis and comparison of effectiveness of intervention in microalbumin

\begin{tabular}{|l|l|l|l|l|}
\hline Micro albumin & Median & Inter quartile range & \multicolumn{2}{|l|}{ Wilcoxon signed rank test } \\
\cline { 4 - 5 } & & & Z & P \\
\hline BT & 143.5 & $62.75-229.50$ & 3.825 & $<0.001$ \\
\hline AT & 26.0 & $16.0-93.0$ & & \\
\hline
\end{tabular}

Table 5: Analysis and comparison of effectiveness of intervention in urinary albumin

\begin{tabular}{|l|l|l|l|l|}
\hline \multirow{2}{*}{ Microalbumin } & BT & AT & \\
\cline { 2 - 4 } & N & $\%$ & N & $\%$ \\
\hline Group 1 (0-30) & 0 & 0 & 13 & 65.0 \\
\hline Group 3 (100-200) & 6 & 30.0 & 3 & 15.0 \\
\hline Group 4 (200-300) & 5 & 25.0 & 3 & 15.0 \\
\hline Total & 9 & 45.0 & 1 & 5.0 \\
\hline Wilcoxon signed rank test & 20 & 100.0 & 20 & 100.0 \\
\hline BT-AT & & & \\
\hline
\end{tabular}

Table 6: Analysis and comparison of effectiveness of intervention in urinary sugar

\begin{tabular}{|l|l|l|l|l|}
\hline Wilcoxon signed rank test & \multicolumn{3}{l|}{} & Z \\
\hline BT-AT & BT & \multicolumn{2}{l|}{} \\
\hline Urine Sugar & N & $\%$ & AT & .002 \\
\hline Nil & 8 & 40.0 & N & $\%$ \\
\hline $1 \%$ & 3 & 15.0 & 3 & 85.0 \\
\hline $1.5 \%$ & 2 & 10.0 & 0 & 15.0 \\
\hline $2 \%$ & 7 & 35.0 & 0 & 0 \\
\hline Total & 20 & 100.0 & 20 & 0 \\
\hline
\end{tabular}

Table 7: Analysis and comparison of effectiveness of intervention in SBP

\begin{tabular}{|l|l|l|l|l|l|}
\hline & N & SBP & Paired test \\
\cline { 3 - 5 } & & Mean & Sd & T & P \\
\hline BT & 20 & 153.00 & 18.62 & 3.735 & .001 \\
\hline AT & 20 & 142.10 & 15.14 & & \\
\hline
\end{tabular}

Table 8: Analysis and comparison of effectiveness of intervention in DBP

\begin{tabular}{|l|l|l|l|l|l|}
\hline & N & DBP & Paired test \\
\cline { 2 - 4 } & & Mean & Sd & T & P \\
\hline BT & 20 & 84.80 & 6.76 & 3.052 & .007 \\
\hline AT & 20 & 79.50 & 6.22 & & \\
\hline
\end{tabular}


Table 9: Analysis and comparison of effectiveness of intervention in S. Cholesterol

\begin{tabular}{|l|l|l|l|l|l|}
\hline & N & S. Cholesterol & Paired t test \\
\cline { 2 - 4 } & Mean & Sd & T & P \\
\hline BT & 20 & 215.80 & 38.76 & 6.678 & $<0.001$ \\
\hline AT & 20 & 184.30 & 27.96 & & \\
\hline
\end{tabular}

\section{Preliminary Data evaluation}

$55 \%$ of the patients were over 60years of age and only $25 \%$ were observed below 50 years of age, $75 \%$ of total patients being male. This suggests the late identification of the disease and fast progression of complications in them. The disease shows more strength in graduated people as with education, a change in lifestyle was achieved. $60 \%$ of them were from middle income groups and $50 \%$ live in urban area and $50 \%$ lead a sedentary lifestyle with occasional exercise. All this have direct relation with etio-pathogenisis of the disease. Most of them were from a Hindu community, suggesting the community of population residing in this area. About $90 \%$ of them were married, with the same percentage being taking mixed diet consisting of diary, plant, poultry meat and fish ethnic to this area. $70 \%$ of these individuals suffered from loss of appetite and chronic constipation and about $90 \%$ have disturbed/irregular sleep pattern. More than $75 \%$ of patients suffered the disease for more than 6years, $40 \%$ being above 10years suggestive of inability to control their blood sugar leading to prolongation of disease and onset of complications. $65 \%$ of patients participating in the study were insulin users for more than 5 years and suggestive of lack of effectiveness in controlling diabetes even with insulin therapy. This is also due to improper time, method and dosage of insulin in them. $80 \%$ of them had diabetes running in the family and the genes responsible for the disease were carried over to them too. Associated illness like hypertension and dyslipidemia which are underlying culprits in renal failure were also found in 55\% of study subjects. Only $20 \%$ of them had other renal issues like calcium oxalate, carbonate crystals and elevated RFT values. All but two, had associated microvascular complications, mostly neuropathies and seldom retinopathies attributed to them. Abnormal eating patterns and sedentary lifestyle are triggers in upcoming diabetes. Genetic predisposition and associated illness were also contributors to this disease. It affects all groups of the population, with an inclination towards urban middle and upper middle-class groups. The current treatment goals aren't sufficient enough to cater all population of diabetics as achieving a good glycemic control is the key to the situation. Associated health issues set in early with array of complications, which makes it further difficult to treat this disease. These symptomatic discomforts are the most worrying to diabetics as their quality of living takes a new low.

\section{Interpretation of Data related to effectiveness of treatment}

Symptomatic parameters saw normalcy as restoration of Sama Agni and Madhyamakosta were seen during and after the study. Significant changes were noted in the quantity and turbidity of the urine, nocturia and frequency of urination reduced. Associated Upadravas like Karapada Daha, Pindikodwesta (burning sensation in foot and palms, calf cramps) although mentioned in Purvarupa saw a change in a week, similarly joint pain and numbness was significantly reduced in 2 weeks, by this it can be evaluated that the drug is effective in tackling underlying neuropathies also. Atisweda and Daurgandhya (excess sweat and smell) due to Medo Dusti has seen a notable reduction. In other systemic diseases, odema in foot saw a significant reduction, especially in patients with associated renal disabilities. Patients with oxalate and carbonate crystals, altered RFT values showed normalcy in urine and blood reports after the study. Other notable changes include healing of recurrent foot ulcers in diabetic patients. Itching in genitals and extremities also were seen reduced. Patients were enthusiastic and noted less fatigue and drowsiness during the day. As far as the biochemical parameters go, significant statistical improvement 
was noted in glycemic indices like FBS, PPBS and $\mathrm{Hb}_{1}$ Ac. The drug thus brings about an overall good glycemic control. The reduction of $\mathrm{Hb}_{1} \mathrm{Ac}$ is a significant finding as it changes only over a 3-month period, shows the rapid and specific drug action in curing the disease. Coming to Microalbuminuria, significant change to normalcy was noted in patients having micro albumin level below 100units. This might be due to the fact that by recent onset and timely intervention, promotes better healing environment to the kidneys along with good glycemic control and reduction in systolic blood pressure promoting reduced vascular permeability. Micro albumin level more than 200 up to 300 units was challenging to the study drug due to the chronicity and increased damage to renal tissues built over years of sustenance. Out of them only a few dropped to normalcy, but in majority cases, the micro albumin level decreased to 100 or below. This is also a significant finding as micro albumin levels only show a change over a period of 3 months. The same could not be achieved by oral/insulin medication alone, showed a positive shift by the add-on usage of the study drug. During the follow up period, reappearance of micro albumin was seen in patients after a period of 1-2 months. Patients below 100 units showed significant resistance to renal damage during follow up period by being normo albuminic after following up period. Some above 200 units showed recurrence to a lower grade. It was also associated with abstinence from the dietary/activity inputs followed during the study period. The drug was significant only during the study period in these patients and it didn't help in completely curing the renal damage. Although in these cases, one could note that the glycemic indices were well and within normal, but urinary albumin and sugar reappeared. It is to be noted that these values didn't speak up as before the drug administration, which points to the reparative action of the study drug.

\section{DISCUSSION AND CONCLUSION}

The study was conducted after preparation of the study drug. In the Out Patient Department of Rasashastra and Bhaisajya Kalpana, initially a generalized screening for diabetic patients was conducted while keeping the inclusion exclusion criteria in mind. In that urine albumin examination was included and those cases who reported albumin in urine were asked to go for specific Microalbuminuria tests. Positive tested patients were asked to sign up for the research study. A total of 20 cases were treated with the study drug and the changes were noted. Tarakeswara rasa was provided in packets of $125 \mathrm{mg}$ and was administered twice daily along with 2-3 drops of honey after food, twice a day for 30days. Subsequently dried Udumbaraphala of $3 \mathrm{~g}$ was to be taken with warm water. They were given a detailed diet and exercise chart to follow for a period of 30 days. Although 1g was the dosage mentioned as per classical reference, it was reduced to one fourth. Considering the least daily dosage among the Bhasmas is Rasasindura and equal addition of Abhraka, Vanga and Loha Bhasmas to compound the formulation cause a decline in the dosage. Subsequent reduction in Anupana was also done from $12 \mathrm{~g}$ to $3 \mathrm{~g}$. Patients were advised to grind the bhasmas with sufficient honey for 5 minutes to ensure an even dispersion of the drug. Each week patients were reviewed for the symptomatic change and biochemical tests were carried out after 15 and 30 days. Data collection was done by using case sheet and lab investigations. Patients were asked to write their daily food and water intake. This gives an idea on the diet patterns by those patients and whether they followed the diet chart provided to them. Subsequently a follow up was also conducted after 30 days to review the changes in the parameters.

\section{Mode of action of the Drug}

Mutravaha Srotas ensures proper formation, carrying and elimination of Mutra in the body. In Ayurveda $\mathrm{Mu}-$ tra is assigned the function of Kledavahanam. Kleda when normal is present in all dhatus causing softening and loosening of solid materials on an account of its Drava, Snigdha and Mridu Gunas. But when Kleda is in excess it should be eliminated as Mala. Whenever the normal liquid portion/Kleda increases in Dhatus as a result of metabolism or by some pathology, it is to be eliminated mainly through Mootra. Hence Kleda holds a functional importance with respect to mutra and therefore in normal functioning of body. Kleda is described by Dalhana as the Ardra Bhava of Jala Mahabhoota in the body. It is more related to Kapha along 
Tridoshas, but its formation needs pitta also. The function of Pitta is said to be Swedana, Kledasruti etc. and Pitta by Ashrayashrayi Bandha relates to Rakta. By this one can assume this excessive Drava Bhava of the body is carried in the form of Kleda through Rakta. This is substantiated by Vridha Vagbhata in Astanga Sangraha Rasabhediya Adyaya in which Malarupa Kleda causes Krishnata, Dourgandhya and Tanutwa of Rakta. Thus, Kleda can be in close association with Mutra and when this is not properly converted to Mutra and eliminated from the body, it will result in Malasanchayam in Rasadi Dhatus. Kleda thus can also be considered as by-product of metabolism in body like glucose, urea, creatinine. It regulates the urine volume and concentration, by controlling the electrolyte retention and excretion. In patients with diabetic Microalbuminuria, Tridosha and Rakta are vitiated. There is increased improper Kleda Nirvahana which not only causes retention of mala Rupa Kleda in body but Ayana Daurbalya due to increase Drava Rupa Kleda.

The study drugs possess common Dipana, Pachana, Mehagna and Rasayana Gunas. Thus, having both corrective and reparative functions in itself. Abhraka Bhasma holds growth reparative as well as regenerative function at the level of dhatus [Dhatuvivardhana]. It not only is Mehahara but reverses the loss of Dhatu Saramsha by account of Ayana Daurbalya at Mutradhara Kala. Loha Bhasmas addresses KPR Doshas in turn help in correcting Dushita Kleda starting from Jataragni upto dhatwagnis. It is balya rasayana to Dasavidha Dhatus in Prameha. Vanga Bhasmas by its Ruksha Laghu Guna is Kp Dosha Hara. Its target areas are of Mutraroga and Kapha Medo Dusti in Prameha. In microalbuiminuria the targeted actions of Meha Mutraroganasana properties can be understood by Mutrashodana Guna of Vanga. Amapacana Agni Vardhana Guna of Gandhaka corrects the Agnimandhya at Jatara and its Suksma Guna in Rasasindura enables reach of the above Bhasmas upto dhatus. It carries the drugs to the required site and hence repairs Dhatu Dusti. As Sahapana the Shodana, Ropana and Sandhana action of Madhu helps in healing Vrana caused at Ayanamukha due to Atipravrthi Mutravaha Srotas, Rakta-Medo Dosa Harana,
Mutrasangrahaneeya and also Vrana Shodana Ropana Sandhana properties Of Udumbaraphala at level of Mutradharakala is used in correcting basic pathology and repairing structural damage created so far.

Rasa Rasayanatwa of the formulation helps in clearing Srotovaikalya and Ayana Daurbalya due to added functional load over the years. Thus, a global perception of improvement in quality of life of the patient was observed. Hence, Tarakeswara rasa was found effective in managing Microalbuminuria associated with Type (II) DM.

\section{REFERENCES}

1. Joshi SR, Parikh RM. India-diabetes capital of the world now heading towards hypertension; J Assoc Physicians India;2007;55:323-324; NCBI accessed on 27/3/2015.

2. Wild S, Roglic G, Green A, Sicree R, King H. Global prevalence of diabetes estimates for year 2000 and projections for 2030. Diabetes care;2004;27(3);1047-1053; NCBI accessed on 27/3/2015

3. Kumar A, Goel M K, Jain RB, Khanna P, Chaudhary V, India towards diabetes control: key issues. Australas Med J;2013;6(10):524-53; NCBI accessed on 27/3/2015

4. Anjana R M, Ali MK, Pradeepa R, Deepa M, Datta M, Unnikrishnana R, Rema M, Mohan V, the need of obtaining accurate nationwide estimates of diabetes prevalence in India-rationale for a national study on diabetes mellitus. Indian J Med Res; 2011; 133:369380; NCBI accessed on 27/3/2015

5. Seema Abhijeet Kaveeshwar, Jon Cornwall, The current state of diabetes mellitus in India. Australas Med J; Jan 312014;7(1):46-48; NCBI accessed on 27/3/2015: PMCID: PMC3920109

6. Pradeepa R, Rema M, Vignesh J, Deepa M, Deepa R, Mohan V, Prevalance and risk factors of diabetic neuropathy in urban south Indian population. The Chennai urban rural epidemiology study (Cures-55). Diabet Med; 2008; 25:407-412; NCBI accessed on 27/3/2015

7. Ritz E, Zeng X, Diabetic nephropathy-epidemiology in Asia and current state of treatment. Indian J Nephrology;2011April June;21(2):7584; PMCID: PMC3132343; NCBI accessed on 27/3/2015

8. Rajapurkar M M, John GT, Kirpalani A L, Abraham G, Agarwal S K, Almeida A F et al. What do we know about chronic kidney disease in India, First report of Indian CKD registry. BMC Nephrol;2012; 13: 10; NCBI accessed on $27 / 3 / 2015$ 
9. Dasgupta I. Cost of treating Diabetic kidney disease. Indian Journal of Nephrology;2014; 24:3:139-140; accessed on $27 / 3 / 2015$

10. Chowta N K, Pant P, Chowta MN. Microalbuminuria in diabetes mellitus: association with age, sex, weight and creatinine clearance. Indian journal of Nephrology;2009; 19:53-56; accessed on 27/3/2015

11. Sri Acharya basavaraja. Basavarajeeyam. Varanasi: Chaukhambha Krishnadas academy; 2012. Page No.294.

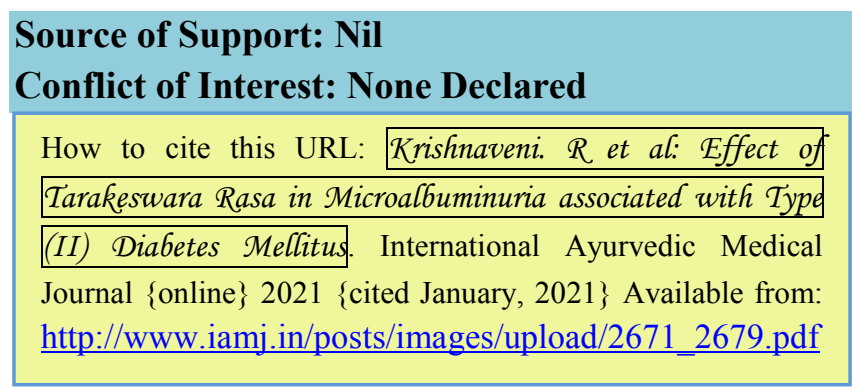

